This article was downloaded by: [Purdue University] On: 17 January 2015, At: 18: 59

Publisher: Routledge

Informa Ltd Registered in England and Wales Registered Number: 1072954 Registered office: Mortimer House, 37-41 Mortimer Street, London W1T 3J H, UK

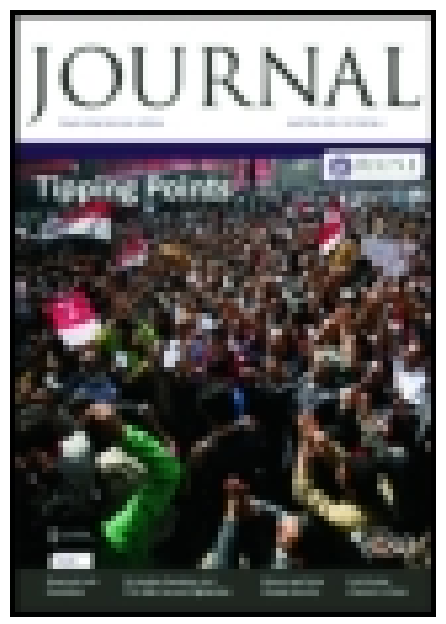

\title{
Royal United
} Services Institution. J ournal

Publication details, including instructions for authors and subscription information: http:// www. tandfonline.com/ loi/rusi 19

\section{Side Armour Versus Armoured Decks, from a Naval Point of View}

Captain C. C. Fitzgerald R.N. Published online: 11 Sep 2009.

To cite this article: Captain C. C. Fitzgerald R. N. (1885) Side Armour Versus Armoured Decks, from a Naval Point of View, Royal United Services Institution. J ournal, 29:128, 63-91, DOI: $10.1080 / 03071848509430462$

To link to this article: http:/ /

dx. doi.org/ 10.1080/03071848509430462

\section{PLEASE SCROLL DOWN FOR ARTICLE}

Taylor \& Francis makes every effort to ensure the accuracy of all the information (the "Content") contained in the publications on our platform. However, Taylor \& Francis, our agents, and our licensors make no representations or warranties whatsoever as to the accuracy, completeness, 
or suitability for any purpose of the Content. Any opinions and views expressed in this publication are the opinions and views of the authors, and are not the views of or endorsed by Taylor \& Francis. The accuracy of the Content should not be relied upon and should be independently verified with primary sources of information. Taylor and Francis shall not be liable for any losses, actions, claims, proceedings, demands, costs, expenses, damages, and other liabilities whatsoever or howsoever caused arising directly or indirectly in connection with, in relation to or arising out of the use of the Content.

This article may be used for research, teaching, and private study purposes. Any substantial or systematic reproduction, redistribution, reselling, loan, sub-licensing, systematic supply, or distribution in any form to anyone is expressly forbidden. Terms \& Conditions of access and use can be found at http://www.tandfonline.com/page/termsand-conditions 
Wednesday, January 21, 1885.

Vicg-Admiral the Riatr Hov. THe EARL OF ClaNifILLLAN, C.B., K.C.MI.G., in the Chair.

\title{
SIDE ARMOUR VERSUS ARMOURED DECKS, FROM $\Lambda$ NAVAL POINT OF VIEW.
}

\author{
By Captain C. C. FitzGerald, R.N.
}

Ir may possibly be thought presumptuous for an Officer who is neither an artillerist, a torpedoist, or a scientist, to offer any opinions upon such a technical point as the respective merits of side armour and armoured decks.

It is therefore with great diffidence, and subject to correction, and from the point of view of a practical seaman, and not as an expert in the different modes of construction, that I venture to approach the subject. Moreover, it is with the view of eliciting the opinions of others, more than of laying down any dogmatic idcas of my own, that I do so.

With such very limited knowledge as wo possess of the points which will govern the result of a fature naval battle, it may almost be said that one man's opinion is as good as another's. At any rate, the opinions of those naval Officers and others, who I hope will speak on this occasion, must necessarily be of some value.

We have such few actual data to guide us towards forming a correct judgment in the matter, that all opinions must be to a great extent speculative; but I cannot help thinking that our sbipbuilders, both public and private, instead of being jealons or offended by the fact of naval Officers discussing in this theatre the relative value of different modes of protection, are far more likely to bo pleased thereat, and anxious to learn the views of practical seamen, gunnery Officers, and any other geniuses who may have opinions to offer upon the extremely important points at issue.

Nor can I believe that our ralers at Whitehall will Jook with dis. farour upon an independent and honest expression of opinion concerning the points $I$ am about to bring before the meeting, always 
premising that in the observations we shall make, we bo guided due sense of loyalty to the authorities, and aroid anything which partake of the nature of criticism of their actions.

I propose in the present paper to confine myself entirely tc consideration of protection against artillery fire, and not to tonc all npon protection against the ram and the torpedo. It may be that any discussion which leares out of account those formic weapons of attack, must necessarily be incomplete and of $]$ valne.

I venture to differ from this riew. In the first place, I know c means of protection against the ram except superior mancouv] power and the subdivision of the ship into nnmerous compartme but eren with the latter derice carried to its fullest extent, I thi most probable that anything like a direct blow of the ram at s between ships of about equal size will ensure the destruction of if not both.

Torpedo defence involves the consideration of wire nets, bo plating, and various other devices, and will, I think, afford enongh for another paper; and I hope it will be taken up by some more competent to deal with it than I am. I' will, therefore, suc to the meeting that they confine themselves to the discussion of the point indicated by the heading of this paper-namely, the respe merits of side armour and armonred decks as a means of protec the ship herself against artillery fire, for I am not.aware that seriously claimed for either of these modes of defence that they form any material safeguard against the ram or the torpedo, a think that if we thrash this subject out thoroughly we shall fin sufficiency of matter to occupy fully all the time at our disposal.

I will assume at starting, and without fear of contradiction, that primary use of all armour is to keep the ship afloat; secondl. protect the magazines, boilers, and steering gear; thirdls, to pri the guns and their crews.

Undoubtedly the greatest calamities which could happen to a in action would be to sink, or to have a magazine blown up; the li would, of course, involve the former, and probably the loss of alı all on board. - Next in gravity to these, I should say, would be perforation of a boiler, or the destruction of the steering gear; ei of these I imagine would entirely disable the ship, and place hi the mercy of her enemies; the majority of the crew might save $t$ lives, but the ship would have to surrender or be destroyed. Ne: importance to these, I should say, would be the disablement of guns, and the slanghter of a large proportion of the crew. $U_{1}$ these circumstances, and in the hands of a determined and gal commander, wo can easily imagine her continuing the action, still endeavouring to rim her enem5, perhaps successfully; and, last resort, if the odds against her were overwhelming, and suppo her to be possessed of high speed, it would always be open to he make what the Americans call "a strategic movement to the $r e$ and sare the remainder of her crew from a foreign prison, and def the enemy of the moral and material advantages of a trophy. 
In order to form any correct estimate of the value of armour, the main point to be considered is the nature of the projectiles which it will probably be called upon to resist. The competition between guns and armour has been going on for a long time, and it will be remembered by many here present that some years ago, when it appeared that the guns were gaining a decided advantage over the armour, and all plates of a practicable thickness were pierced with ease at pointblank range with solid shot from the heavy guns, it was proposed to do away with side armour altogether and to allow the shot to go clean throngh, thus making less splinters than if they had been imperfectly resisted by armour; and as a substitute for side armonr, the device of horizontal armour or armoured decks was adopted in order to protect what are called the vitals of a ship from the indirect blow of partially descending shot, and from the downward effect of the explosion of shell which had passed through the side. This principle bas been adopted entirely in some of our cruizers, and partially in almost all our first class battle-ships-“"ironclads" I was going to call them, but that they are not, in the strict sense of the word, and they base their claim to fighting power upon other qualities.

Now, with all possible respect for the opinions of those who have substituted armoured decks for side armour, I venture to think that they are wrong, and that they have arrived at their conclusions in error, and without assigning their proper value to the various requirements of a war-ship, and of the projectiles which will be used for her destraction. This is plain speaking, but I am not afraid of offeyding anyone, as they will know that my remarks are not personal, and are only offered with the view of eliciting a fair discussion of the subject by seamen and others, and if possible of arriving as near to the truth as may be without the actual experiment of war.

I shall be truly glad, in view of the present designs of our fleet built and building, if the adrocates of armoured decks as a substitute for side armour can prove that I am wrong, or can show plausible rèason for assuming that $I \mathrm{am}$ so. I have thought a good deal npon the subject, and I only offer my opinions as those of a seaman, and not as a scientific shipbuilder, so they must just be taken for what they are worth.

In the "Times" of 4th December I find Sir William Armstrong advocating a large increase in the number of fast unarmoured cruizers for the Navy. These are his words-" Every improvement in guns, projectiles, torpedoes, and methods of ramming, to say nothing of the new modes of attack which science is likely to develop, tend to lower the value of armour, and to equalize the risks of armoured and nnarmoured ships. Upon these grounds I consider that a lavish expenditare upon armoar-clads is to be deprecated, while we cannot be wrong in creating a numerous fleet of swift, heavily armed ships; protected to the ntmost extent obtainable without armour."

He then goes on to discuss the thickness of armoured deck necessary to protect these crnizers, showing thereby that be intends to afford them this protection. Now, as Sir William Armstrong's letter was published in the "Times," and is therefore public property, I vOL. XXIX. 
presume there can be no harm in criticizing it. First, I deI "every improvement in gans and projectiles tends to lower th of armour." The improvement in machine-gun fire, and th six-pounder which fires from ten to fifteen rounds a minute] maintain, a directly contrary tendency.

The increase in the size of guns and weight of projectil probably act in that direction; bat it should be remembered tl number of heary guns carried by a ship must be few and th slow, whereas the development of the fire of extremely quick 1 light shell-gans, which has received so much attention of lat have a directly contrary effect to that indicated by Sir IV strong.

With regard to torpedoes, I don't see what they have got with it, except to point in the direction of bottom armour as pr lately by $\mathrm{Sir}$ E. J. Reed."

I am not aware of any improved methods of ramming, nor if were any, do I see how they could affect the question of armour as to the "new methods of attack which science is liliely to de I submit that so far as we are able to judge of an unknown qu they are as likely to point in one direction as the other. Ho whether my criticisms of Sir WV. Armstrong's opinions are value or not, we know that Sir E. Reed differs from him wic his appreciation of the value of side armour, and when tw authorities disagree, are no not entitled to inquire into the: for ourselves?

The decision to abandon (either partially or entirely) side a arrived at in consequence of the impossibility of keeping out solid shot which struck directly with any practicable thickr armour, appears to me to be erroneous for the following reas First, it appears to me to ignore the fact that armour, which n keep out solid shot, will keep out large capacity shell of thi calibre with heary bursting charges, which, if allowed to ont ship, will do far more damage than any shot; secondly, it set ignore the fact that in actual warfare the great majority enemy's projectiles which strike a ship will not do so at right: nor at point-blank ranges; thirdly, it appears to under-estim: extreme rapidity and terribly destructive effect of the firo 0 guns and machine-guns, every shell from which will enter anc inside the unarmoured part of a ship.

To jump to the conclusion that because you cannot keep out shot it is therefore no use to try and keep out any, appears to be on a parallel with the action of a man who, finding that $h$ leaked on a rainy night, turned to and pulled the roof off altor on the principle that because he could not keep out all the rain, therefore no use trying to keep out any; or of the Captain of who, funding that she had sprung a leak, said " $\mathrm{Oh}$, well, if we have any water in, let's have in as much as possible; open : valres and knock a hole in her bottom." 
I think that in trying to estimate tho true value of side armour as a means of keeping a ship afloat in action, it is neccssary to base all our calculations upon the laws of chance, and not upon the exact thickness of plate which has been pierced by a gun of a certain calibre. The term "laws of chance" may be objected to, and people may say that chance has no laws. Well, I am not particular as to terms so long as I can convey my meaning, and it is quite certain that all life insurance companies base their calculations upon the chances of the most uncertain thing in nature, viz., human life, and I believe they come to tolerably accurate conclusions by so doing.

I suppose we might assume that, roughly speaking, the rapidity of the fire of gans is in the inverse ratio of their size. Let us say, therefore, for the sake of argument, that one of the new six-pounder guns can fire ten shots while the 18-ton gun is fing onc. I may here remark parenthetically that I make no pretence to accaracy in this comparison; it is quite immaterial to $m y$ argument whether it fires ten shots or twenty shots; I only want to prove a principle, and I should say ten shots would be well inside the mark, so let us say ten. Then, I maintain that in all probable engagements (except where a ship which has the speed keeps three or four miles off and plays long bowls) there will be ten times as many chances of hitting a ship with a six-ponnder as with an 18-ton gun. I expect to hear this statement questioned by some one who will say, " $\mathrm{Oh}$, but the man who fires the 18-ton gun will be so much more careful over his shot, knowing that so much depends upon it, and therefore he will be more likely to make a hit." I will leave this argument for what it is worth, only observing that I have no doubt many herc present have seen the captain of a gun exceedingly anxious to hit, taking a long time aiming and poking ronnd after the target, and then making a much worse shot after all than if he had fired quickly and with his first aim, so that I scarcely think that anxiety to hit need be taken seriously into account as a factor in the case.

Now, lest I should be misunderstood at this point, and it should be supposed that $\mathrm{I}$ am going to adrocato doing away with heary guns in ships, and carrying a large number of light guns instead, I may state briefly that I have no intention of proposing anything of the sort. I think that both heavy and light guns will have their respective parts to play, and one will support the other: bat what I do propose to submit to the meeting are the following points :-That in viow of the recent development of light and machine-gun fire, no iron ship is fit to go into action at all, or to be called a "man of war," which has not got a complete water-line belt of some sort of armour: and that an armoured deck is no substitute for such bolt. Secondly, that a water-line belt of only 3 -inch steel will keep out about twothirds of the projectiles which are likely to be fired against a ship in action; for it will keep out all the machine-gun fire, and most of the light gun fire which strikes obliquely and at long ranges. Thirdly I would submit, that from a naval point of view, it is a grave, naj, a fatal error to leave two-thirds of the water-lines of our line-ofbattle ships absolately unplated, and therefore certain to be penetrated. 
in a hundred places, by the terrible hail of light and machin fire which would be poured upon them in action; seeing that $i$ condition their stability and seaworthiness would be at least dou And finally I wonld submit that eren now, at the eleventh hous in spite of personal feeling, and the mortification it might cal clever men to see their designs altered; yet for the honour safety of the country, and the credit of the Navy, the whole o so-called citadel ships should be altered immediately, no matter it may cost; the whole of the armoured deck should be taken: except patches to cover the crowns of the magazines; and if I sary, some other weights taken out, coal, or evon guns and am tion, so as to enable them to be given a complete water-line $b$. whatever thickness was found to be practicable; but at least enough to keep out light and machine-gan fire.

I expect that, at first, most naval Officers and all naval arch will laugh at this proposal; and I shall hear the words "imposs and " not worth it": but yet I beg of them to consider this $\mathrm{m}$ deeply, and try to weigh in their own minds what the various ch of a modern naval battle will be; giving special attention to th of hole which even the 1-inch Nordenfelt gan makes in thin iro: steel, and the extreme difficulty of getting at and stopping those if they are in the region of the water-line; and also the great bability of a large number of such holes being in the region o water-line, even if it is not aimed for.

These citadel ships are no discredit to their designers; for it he remembered that the development of machine-gan fire, and o rapid firing light guns, has taken place since they were desig but now that we are face to face with these instruments of des tion, which would seem almost to have been invented on purpc deal with our battle-ships, wo must look at the matter boldly not attempt to shirk it, bat take the necessary steps to frustrate deadly effect.

It is often easier to convey one's ideas by means of an illustr than by any other means; and as I think that the probability $o$ belted, or partially belted iron ships being sunk in action, has very much under-rated, I propose, by way of illustration, to con the relative chances of success between a completely belted an entirely unbelted ship. I will take, for example, the "Hercales" the "Italia." Now, I dare say most of my hearers are tolerably acquainted with the respective arrangements of these ships. "Hercules" is about twenty years old, and may therefore be consic as embodying all our knowledge and skill at that period. Since great advances have been made in the size and power of guns, al the resisting power of armour. Mloreorer, the "Italin" is $\mathbf{n}$ double the size of the "Hercules;" and yet I renture to think th a pitched battle, the chances in farour of the "Hercules" destrc the "Italia" before the "Italia" could destroy her, would be great. Mind, I say the chances, for I am quite aware that the first from the "Italia " might destroy the "Hercules;" but I say the ch are against it. These two ships are fairly typical of an armo 
belt versus an armoured nnder-water deck, though the "Italia" being so much larger and so much newer, ought of course to be immeasurably the stronger.

Their respective characteristics are somewhat as follows:-The "Hercules" has a complete belt round her water-line of 9 inches amidships, tapering off to less at the ends. She has eight 18-ton guns in a battery, protected with armour varying from 8 to 6 inches: her other light and machine-guns, in the tops and elsewhere, would be unprotected by armour.

The "Italia" carries four guns of enormous power (100 tons each) which with their communications to the magazine below the armoured deck, are protected by armour of great thickness; all her other gans, and the whole extent of her water-line are absolutely unprotected, even from the fire of heavy machine-guns.

Now, if the "Italia" and the "Hercules" were to meet at sea as enemies, the "Italia" with her superior speed would have three courses open to her. First, she could run away, which would probably be her wisest course; secondly, she could use her speed to keep out of range of the "Hercules's" guns, which would be a long way, though I am not prepared to say how many miles; and she could fire at the "Hercules," with hor four heavy guns. This is a course which we often hear adrocated for ships with great speed and heavy guns; but it is a course which I cannot believe would ever prove decisive. I shonld think that with both ships in motion, and the "Hercules" end-on, as of courso she would keep herself, the chances of the "Italia" ever hitting her, would be very small indeed ; so that after the battle had lasted for about a fortnight, which I take to be about the time that the "Italia's" ammunition would last, at the average rate of firing of the 100-ton gun, she would have to bear up, and go into harbour for more.

The third course open to the "Italia" would be to close with the "Hercules" and fight it out. Let ns, under these circumstances, consider what their respective chances would be. Now; it appears to me that if the "Italia" did not sink the "Hercules" by striking her at the water-line with the very first discharge of her heary gans, which I submit is a somewhat remote chance; then the "Hercules" would certainly put the "Italia" in a sinking condition before she could fire another shot with those heavy guns.

I am informed by an experienced gunnery Officer that the 100-ton gun cannot be expected to fire more than one round in a quarter of an hour' or twenty minutes : during this interval the battle would take place ander the following conditions. Both ships would discharge at each other a perfect hail of light and machine-gun fire, so that we might expect that in a quarter of an hour's time, each ship's side would exhibit what gunmakers call a pretty good pattern of of either shot holes or shot marks; and I submit that even if the firing were of the wildest description, and the water-line not even aimed for, that according to the laws of chance that $I$ am so fond of quoting, a very considerable proportion of those shot marks would be in the dangerous region of the water-line; but there would be this 
difference, in the case of the "Hercules" they would be shot m: and in the case of the "Italia" they would be shot holes. It is fair to suppose that the battle takes place either in a gale of $\pi$ or in a flat calm without swell; it is fairer to suppose that arerage weather, what sailors call a royal breeze, and a slight si and ander these circumstances, with the motion of the ships, and wares washing ap and down their sides, I suppose that we might sider a belt of 5 or 6 feet wide to be the dangerous area or regio the water-line. Does anyone suppose that if the "Italia" had ceived her fair average proportion of shot in this region, that would not be in a sinking condidion?

I think that if we consider the sort of holes that eren small make in iron and steel, and the great difficulty of stopping them, she most certainly would. She would, howerer, have the optio capsizing first if she chose it, by keeping the water above her armo deck, and not allowing it to go below. It is of very little consequ to say that her heavy gans, and the men working them are perfe protected, if the structure which carries them is sinking, or in minent danger of capsizing. Moreover, in addition to the duel tween the light guns which would go on while the "Italia" was loading, the " Hercules" would have her eight 18-ton guns prote by tolerably thick armour, and firing a round a minute; the $l_{\text {: }}$ capacity shell from which would pierce the "Italin" all over, ex just on the citadel, and exploded inside above the armoured d would very soon make short work of compartments, cork stuf coffer dams, or any other devices for keeping these peculiarly signed ships afloat. I think there wonld be very little doubt a the result of the action; at any rate I know which of the two shi would rather be in.

It may be asked why I have selected the "Italin" for compari seeing that we have no ship of such a type in our Navy. It is that we have no ship of exactly her type, but she is a fair speci: of carrying to its fullest extent the principle of leaving the water-] or any part of the water-line, of a battle-ship unarmoured.

It is not my intention here to enter into the controversy which been already so hotly carricd on as to what the condition of citadel ships will be with their ends riddled, and the water flov freely in above the armoured deck; whether they will be safe, sta and seaworthy, and able to fight their guns; whether they acquire such a heavy list as to be unable to fight their guns; whe they will be so waterlogged as to become practically unmanagea: or whether they will turn bottom up altogether, as broadly hir by Sir E. Reed in this theatre a short time ago, are points whic do not propose to discuss on the present occasion. They are po which I am not competent to discuss, but I submit that, as exp disagree upon them, they cannot be considered to be satisfacto disposed of, either by calculations on paper, or by the trial of mo in smooth water, or in any other way than by the trial of the : herself in rough water, with most of her coal and stores expended

It would be highly presumptnous on my part to assume to speal 
the name of the Navy, but I hare given some consideration and thought to the subject of these citadel ships, and have conversed with many experienced seamen concerning them; and I have come to the conclusion in my own mind that the Nary does not like them-lhas no faith in them, in short-and would much prefer to see even thin armour carried completely round the water-line, at the sacrifice of some other weights. I have been informed by an expert (not after calculation, but roughly, and at a guess) that the "Addmiral" class could carry armour of about 9 inches thick, as a water-line belt for their ends, if the horizontal armour and thwart-ship bulkhead were removed; and I imagine that most seamen would rather fight them in that condition than as they are at present. No naval Officer, I make bold to say, would have the slightest objection to be sunk by the shot from a 100-ton gan if it hit in the right place, but to be sunk or disabled in a supposed ironclad by tho fire of every popgun carried by every foreign gunboat, would be more than the honour of the Britislt Nary could survire.

I have had the internal arrangements of the nnarmoured ends of the citadel ships carefully explained to me-the rarious devices by means of coffer-dams, \&c., for getting rid of the water which would come through shot holes in the region of the water-line; also the value which is placed upon stores and coal for keeping out a certain amount of the water; and I am bound to say that, with all respect for the ingenious minds which have devised these pluns, they do not commond themselves to my judgment, as a seaman, as being practical devices, or at all competent to deal with the destruction, and consequent heary flooding of water, which I anticipate for these unarmoured ends in action, principally from the fire of very light and machineguns.

The citadel ships appear to have been designed under the impression that nothing would be fired against an ironclad in action except heary shot at point-blank ranges, and that therefore, as it was impossible with nny armour of practicable thickness to keep out heary shot at point-blank ranges from the whole length of the waterline, it was better to keep them out from a part, and trust to cork filling, numerous compartments, coffer-dams, stowage of stores, and an under-water armoured deck, as sulsstitutes for armour for twothirds of the length of the ship.

But I submit that this is a total misconception of what will occur in a general, or even in a single action, and that, as a matter of fact, the vast majority of projectiles fired will be of very small calibre, and such as vers moderato armour would have kept out. It also seems to have been forgetten that several small holes will let in as much water as one big one, and that the chances of hitting a ship's water-line will be in proportion to the rapidity of fire. I believe, therefore, that I understated the case when I said, a little further back, that I thought a 3-inch belt of steel would keep out two-thirds of the projectiles fired in action, which would otherwise have penetrated an unarmoured water-line.

Mrst we not also snppose that our possible enemies, knowing the 
construction of our battle-ships as rell as we do, will give spe attention to the derelopment of light gun-fire, so as to take advant. of our weak points? And will they not direct all their shot: shell, too, to our unarmoured ends, leaving the impregnable cita to be put out of action and rendered useless by the destruction of weak and unstable platform upon which it depended? I think may give them credit for that much intelligence.

Let us now consider how far an armoured deck is a sabstitute side armour, for it must bo remembered that an armoured deck is considerable weight, and unless it can be shown that the distribut of weight in this form affords better protection to a ship than same weight as side armour, there can be nothing to say in favou it. An armoured deck protects the magazines from shell-fire, and the case of cruizers without side armour, it protects tho tops of boilers, and, I presume, the steering connection; but a very sn quantity - small patches, in fact- of horizontal armour would prol the magazines and boilers, and an armoured tube would protect steering connection. An armonred deck, therefore, is intended fulfil another purpose, namely, to Jeep a certain portion of the s intact and watertight after her upper works and water-line bare $b$ riddled by shot aud shell. Now the question which forces itself $u_{]}$ one's mind is this-is it worth while, at the expense of so mi weight, in the shape of horizontal armour, to keep intact a cart portion of the ship already beneath the water, and thus represent no reserve of stability or floating power? In the case of the "Itali for instance, and in some of our own cruizers with under-wo armoured decks, the effect of keeping the lower portion of the s intact, whilst the water conld flow freely in through her ridd topsides, would be simply to capsize her. 'This must bo obrious the inost unscientific mind.

I have already said that I do not propose to enter into the c troversy as to the ceaworthiness or otherwise of our new first c] battle-ships, with their ends riddled. There will always be a ference of opinion upon that point antil one of them has been tri but the best that can be said of them is that they are hermaphrod: -half cruizer, half ironclad; or, as far as their water-lines are c cerned, two-thirds cruizer, and one-third ironclad.

To an ordinary nautical mind, it would veally appear that under-water armoured deck, the coffer-dams, cork chambers, : numerous compartments had been specially and ingeniously devi: for dealing with water which had been allowed to get inside the sh and which need never have been permitted to do so. It will like dealing with a very troublesome burglar, whom you have allon to enter your house, and then have to deal with inside, instead taking proper precautions to exclude him, and then arguiug the po with him, if necessary, while he is outsidc.

I observe that in some of the new designs the armoured decks cruizers are to be a foot above water, sloping down to 4 feet un water at the sides, thus :- 


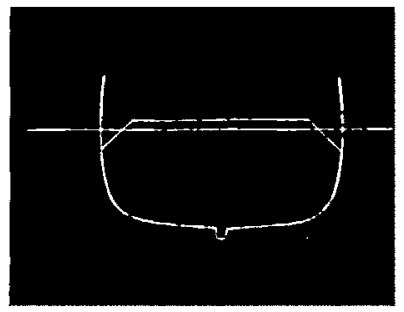

This seems to be a step in the right direction, for it must be remembered that any intact space which is above the water represents a reserve of Eloating power, and that the ship can never sink as long as she has only a few inches of such reserve; neither can the water gain upon her so long as she retains it, no matter how much her topsides and water-line may be riddled, as it will flow out as fast as it flows in. But even with this new design, I cannot help thinking that, in view of the recent development of machine and light gun-fire, the armour used for the deck would have been better distributed as a moderato belt of side armour, with, perhaps, small sloping patches over the crowns of magazines and boilers.

I have laid before the meeting $\mathrm{my}$ views upon the question of side armour versus armoured decks as means of keeping a ship afloat in action, for, as Sir E. Reed pertinently remarked in this theatre a short time ago, "the first duty of a ship is to float;" and I trust that any naval Officers or others who have given any thought to the subject, will give us their views upon it. I have founded my arguments upon what I believe to be the only reasonable foundation, namely, the laws of chance.

We naval Officers do not claim to be shipbuilders, but we do claim to be seamen, and to know something about the sea and its unruly nature. As a matter of history, we know that our fathers did not rale the waves in tin pots with numerous holes in them; and as a matter of speculation, I do not think that we shall do so, either.

Admiral Sir R. Spexcer Robrxsox: Lord Clanwilliam, ladies, and gentlemen, I have some diffidence in getting up so early in this discussion and giring $m y$ opinion upon this matter, but I think at any rate jou will agree with me, that the views that our worthy and excellent friend, Captain FitzGerald, has giren hare shown good sense, moderation, and impartiality which are bejond all praise. In the obserrations I shall make I will endearour as much as possible to keep to the sub. ject he has put before us, and not to wander out into many discursire points which are a great temptation to us when we come to discuss our fighting ships. I know rery well, nobody knows better, that those parts of the designing of a ship that depend on the naval architect cannot rery well or very aceurately be discussed in this theatre, first of all because speaking for mjself, and I beliere I may the same of many naral Officers, we hare not the requisite hnowledge to discuss matters of purc naral architecture, and, if we had, the time it would take, the drawings we should hare to consult, the plans we should have to bring forward, and the various models and calculations we should have to go through to establish any position we might take up against the riews of a naral architect when he bas designed $a$ ship, 
would certainly prerent the result being at all satisfactory. Another thing beliere, we are bound by a rule not to go rery much bejond 10 or 12 minut the obserrations we hare to make, but I trust if I go a little bejond my time, I is extremely likely, in order to say what I wish to sny, you will excuse me pernit the infraction of a rule which ought generally to be rers well obsc Before I start upon some obserrations upon the ships, I wish to say how Captain FitzGerald has pointed out that the doctrine of chances is not, and not to be, overlooked by us in our consideration of naval battles. Every Offeer mill remember that fine saying of Nelson before one of his great bo that "Nothing is sure in a sea-fight above all others; something must be le chance, for shot will carry aray the masts of friends as well as of foes." S doctrine of chance will sometimes hit us where my worthy friend wants to $b$ and Eometimes it will hit us unfairly, to which he verr much objects, and so I hold in my hand a paper, which I will proceed to explain to you. I want I this. I am going to confine my remarks to the eitadel ships, they being lar number, and of the first class of our battle-ships. I leare otlier people to di the rarious points relating to our cruizing ships, which I think will lead to much discussion indeed. You all know what I mean by a citadel ship, fo phrase is commonly used. First, a citadel ship has a certain portion, in my $m$ very limited portion, defended by armour-plate, and a rery considerable pe protected by coals, by an armour deck below water, by coffer-dams, by cells, by and all sorts of things. The effect of that protection we shall hereafter cor discuss when I shall compare the effect of a ship defended by contrirances, a what we all understand as nrmour-plating. There are eleren of these ships, a will gire their names, and the way in which $I$ hare classifed them. Ther very considerable difference between the original citadel ships and the later and a considerable adrantage in the later ships. The original citadel ship wr "Infiexible;" then there come the " Agamemnon," the "Ajax," the "Edinbu the "Colossus" and (though not exactly the same sort of ship yet somewhat lar), the "Collingwood." "The first fire are so nearly alike that I may cor them of the same trpe, and call them Class A. The "Collingwood" differs a from that type; therefore I say our first type consists of fire or six. After those are the "Howe," the "Rodney" (Class B), the "Camperdown," the "Benl and the "Anson" (Class C). All these ships differ, and the type is rery raried by what has been done. Here are the facts of the casc. I hare take: table from one publislied in the "Times" the other das, as the result of a le giren by Mr. Barnaby, the Chief Constructor, at the College of Naral Arehi The frist thing that strikes me os something rather formidable is that in "Inflexible" only 42 per cent. of the area of water-line is protected by armous 58 per cent. of the area of water-line is defended by what 1 hare called c. rances. We go on to the "Agamemnon" and the "Ajax," and we find 45 ; fraction per cent. of the area of water-Iine defended by armour, the remain the area of water-line being defended by contrirances. This seems rather to struck the constructors as not being quite a proper thing, and they designed two a little different, but the percentage of which was only $42 \frac{3}{4}$ of the area of wate protected by armour, the remainder being defended by contrirances. Thes the first five ships in my Class $A$. But here comes another one, the "Collingw her dimensions resembling in erery respect the actual dimensions of the " burgh" and the "Colossus," but she differs from them in this particular, thi has 54 per cent. of the area of rater-line protected by armour, and the reme only defended by contrivances. It seems, therefore, as if it was not at all unn: in us to view with alarm and distrust the rery large area of water-line imper defended, as we think, in the earlier ships. It eeems that we are right, becau naval constructor has added to the percentage of protected water-line rer: siderably, and to the next two ships, which are the "Rodney" and the "Hi (Class 1), he has added still more. My argument is this, that the rery desi of these ships either were horrified or repentant at the rery small area of line that they had protected by armour, and so they adranced from 42 to 56 : fraction per cent. of water-line protected by armour. If they had the same fidence in their contrivances for protection of the ship's ends unarmoured 
they designed the "Camperdown" as they liad when they designed the "Inllexible," we should not hare had any improvement. They have been convinced either by their inner consciousness or by the arguments of those who consider the armour protection of the ships insufficient, to adrance from 42 to 56 per cent. All I can say about that matter is, go on and improre; don't stop where you hare come to, give us that protection which rou evidently think necessary, in a larger measure than in the "Camperdown," the Class $O$ that you bare recently designed. Bnt there are other and still more serious features in this table. One is that if the ends protected by contrirances are riddled and destrosecl, in one case 750 tons of water will come into the ship; in other cases it diminishes, as in the "A jax" and "Agamemnon," to 580 tons, and then to 570 tons, 550 tons, 450 tons, and 420 tons. Now here there has been progress made, and I think naral Officer's ought to be extremely gratified with it, but I would still say "Go on and improre, correct the errors of your ways wholly, and girc us the same proportionate protection to the ends of our ships that you hare giren to the central citadel." The ends do a certain proportion of the work of the ship in maintaining buoyancy, and stability, and handiness, and they ought to hare as large a proportion defended as the citadel part of the ship. Now $I$ do not hesitate to say that it is my opinion, and the opinion of almost erery naral Officer with whom $\stackrel{I}{\mathrm{I}}$ hare con. rersed, that contrivances do not gire the same protection and security to the ends of the ship as the armour-plating gives to the central citadel. I say the ends of the ship have a certain part to do in maintaining the efficiency of the ship as a fighting ship, and unless they are giren that proportion of defence which they ought to hare, the citadel is of no use. I am very much strengthened in holding this opinion by what passed in this theatre a short time ago. I listened, a? all present did, with the greatest interest to the thoughtful, careful, uneraggerated vien of the case presented to us by my friend Sir Edward Reed. Most eloquently, and at the same time almost pathetically, he showed us the risks that might be run by a ship going from under our feet, and that there night be the loss of honour to our flag, and of a great vessel. There was no exaggeration, no endearour to drag forward or find fault with the short-comings of other napal designers. He held these things up to us for the consideration of naval Officers, that we might express by such means our opinions as to whether the citadel ship was properly supported and protected by its unarmoured ends being defended by contrirances. We all remember that great and horrible controrersy (I cannot call it anything else than horrible, for I nerer felt more pain than in reading the letters) in which scientifie matters that ought to be decided realiy upon their merits and experiments were made a rehicle of all manner of personal ill-will and abuse. I refer to that no further, except to say that those who took part in the composition of the Report laid before the Admiralty on the state of the "Inflexible" made many recommendations, the whole of which, as far as I know, hare been disregarded. You hare only to turn to the Report of the "Inflexible" Committee to see that one of the things they laid the greatest stress upon was that proper, thorough, and exhaustire experiments should be made as to whether these contrirances of coal, cork, cells, coffer-dams, and so on, were or were not sufficient protection. Of the under-mater deck I speak with the greatest respect; I do not know that I go so far as Captain FitzGerald in wishing to do away with it. . For my part I take off $\mathrm{my}$ hat to the under-water deck, and respect it rery greatly. It was an extremely judicious help. But we were told by that Committee that no sufficient experiments had eror been tried, as was pointed out by Sir Edward Reed at the time, as to what effect would be produced upon all these contrirances under a heavy artillery fire. Now if it were a question of what effect 500 tons of water would hare on the position of the centre of grarity, I would take the opinion of a naral architect or constructor of experience. without question. I believe they are perfectly qualifed to gire answers to that question to the satisfaction of any reasonable man, but $I$ will not take, nor will I ask naral Officers to take, the opinion of a naral constructor as to the rarages of shot and shell. Knowing that naval men will have to risk their lires, I claim that they shall not be sent out without as much knowledge of the possibility of their ships being defended by theso contrivances as they have with regard to thick armour-plating. We know very well that thick armour-plate is not infallible, but we have ascer- 
tained by a serics of experiments what armour.plating can do. Wh "Warrior" mas built, target after target of $4 \frac{1}{2}$-inch armour was fired at by guns of those days, and until rifled guns appeared targets were successful. $M y$ Sir Edward Reed brought forward a ship, the "Bellerophon," whose armourkept out eren rifled guns of small power, but he went much further. Bef "IIercules" or the "Bellerophon" was built, these experiments were ma thicker plates, and they kept out the shot and shell. 'I he "Hercules"' penetrated, and gare naturally to erery naral Officer a degree of confidenco I must say they are now without. Repeated experiments were further made were fired at the "Glatton" with the turrets in their place, and the resul। satisfactory. Then we tried whether the derice of taking two thicknesses of a plate was equal to one thickness, and it was prored satisfactorils that twc nesses would resist as woll as an equiralent thickness in one armour-plate. ascertained in a mathematical form what armour-plating will do, its ralue is when we go into action; we take our ships into action with a certainty 1 have in them a resisting power which we know of and can measure, but 1 the least idea of what the resisting power of all these contrivances will be hare affirmation, certainly. We hare it affirmed that it is extremely imp: that all these contrirances will be destrosed, but if a large portion were des would not the ship's buoyancy, stability, and steering power be lost, and her as a fighting ship be almost nowhere? We hare no satisfactory knowledge a what will be the ralue of these contrirances by which alone our first class sl to be maintained efficient, and I ask my brother Officers, if they think as I use erery erertion in their power, by discussion, or by writing to nemspapers, any other means they possess of influencing public opinion, to cause thorough searching experiments to be made, which shall gire them the same knowl the value of the contrirances as they bave of the citadel of the ship. I a glad Mr. Barnaby published this paper, for of all the things I should most wis in any discussion, it would be not to be dogmatic, not to take an unfarourabl nor to act as an adrocate or a lawyer, and only mention what is unfaroural to take my opponent's riew, and to state why I entirely dissent from the tions he has come to. We are told the loss of buogancy in the "Inflexible total destruction of ber ends is only 750 tons of water. That is a nice thing 1 rolled about the deck, besides anything you may get elsewhere. I am so d. as to whether this is really the maximum that will come into a ship, that I: permitted to make a remark or two upon it. If the total destruction of the system of contrirances ensues, if all the cork and all the cells are blown out ship, and then there are only 750 tons that can get into the ship, I should gir of relief, though the matter would be extremely serious; but I think there is deal more behind it than that, and not haring those plans and sections n should like to have before me, I want to know what happens to a ship, which large a proportion of her contrirances for defence dependent upon the coal a to carry and consume, when that coal gires out, because when sho is witho coal, an action may come on at any moment. The "Inflexible" carries 800 coal as a protection to her water-line; the others do not carry so much; bi will happen when the coal is burnt? I want to know whether those though weighed on the constructors, and have caused them to make some improve We will take it that the $\mathbf{8 0 0}$ tons of coal is expended, and that the ship go action. The coal protection is gone, and there will be 800 tons of water, not, fixed in cells in addition to the racant spaces already flled with water, 700 any less amount walking about the decks doing just as it pleases. Ánybor has seen water in motion knows that there is not a more powerful knocke of every obstacle that comes in its way. The percentage of coal in the "Infl, which is outside the armour-plating is rery much larger than in the others, the very last ships $I$ find 17 . per cent. of the whole area of the ship is fille conl, and outside the area of the armour-plating. That 17 per cent. of cour be more quickly burnt than the 800 tons. Therefore I think the objection to water running about the ship, although rery much less in them, appear: admitted upon the supposition that only the contrirances to defend the unarr cnds will be penetrated, and in disregard of the loss of protection occssioned 
consumption of coal, so at last they hare come down to a minimum admission of 420 tons of water. But $I$ seriously object to that amount of water, increased, as it would be, if you had consumed your coals, and that space had been filled with water by the rarages of artillery. I take it it nerer has been and nerer will be doubted that the sides of the ship will be perforated right and left by sbell fire. What they bid us trust in, is cork in cells, coals, and stores. The most dangerous protection jou can give a ship is a store which Jou must rapidly consume, and without which jou cannot get anywhere. Therefore nothing is so dangerous as the remoral of the couls, and that must take place, and then the figliting powers of the ship are very seriously diminished. The question I have asked myself over and over agaiu is, "Is the maximum of water that con be admitted into the ship fairly giren us by what is called the total destruction of the contrirances, minus the under-water deck ?" If it is, the case is bad enough, but it is not quite so serious now as it was formerly. I have detained you by these obserrations, and I will not procecd any further, more tban to say that we ourselres as naral Officers hare a great dislike to the citadel ship. The highest possible authority has described the erils of the citadel ship in guarded and moderate languare: I mean Sir Edward Reed. We have our own thoughts as naral Officers, and they have a right to be heard. Not only that, but the opinions of the highest authorities and designers of ships are on our side. We hare the strongest possible corroboration that we are right by the breaking up of the extreme principle which mas enforced in the "Inflexible," and we hare come down now to a rery much more extended ciladel. I think the citadel in the "Camperdown," the "Benbow," and the "Anson" is 150 feet long, while in the "Inflexible," a considerably larger ship, it was only 110 fect. Wo ask them to go on in the good way they hare begun. We tako their admission as candidly as we possibly can without exaggeration; we take the alterations they hare made as a proof that our views are worthy of consideration, and that they are partly adopted by the constructors of the day. I therefore say let us hare an experiment that will prore what Captain FitzGerald and others hare said, but which not only has been denied offeially by naral construetors, but I am sorrs to say does not appear to have gone down rery well with some naral Oflicers and some experimentalizers, whose positions I should not like to impugn, but from whom I differ very mueh. These experiments can be tried by our naral authorities. There is no doubt a slighter and thinner belt than that on the citadel can be extended as nearly to the ends of the ship, if not quite, as will make the area of water-line unprotected by armour-piates so small as not to be of rery great moment, but at the same time I should like it to be thoroughly understood that the opinion of the Nary will be this, that you should not absolutely insist on this in exceptional cases, but for battle-ships. It may not be possible to continue the armour towards the bow of the ship of the same theikness and weight that jou use at the micldle and other parts, and we do not insist upon this. I do not know whether any naral architects are present, but I hope that nothing $I$ hare said has been in the least offensive to any one. That is the rery last thing I should wish to do. I hope the maintenance of my, opinion without the adrantage of their concurrenco will not offend them. Their ingenuity and skill, as I well know, are quite capable of finding the requisite remedies for the evils which I hare pointed out. If they do that they nill add another wreath to the laurels which they have already won in their most meritorious and hardworking profession.

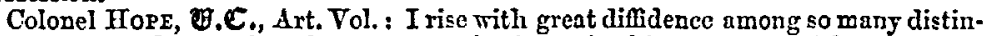
guished naval Officers, but there are certain things in this question which necessarily occupy the attention of artillerists, and as such I bare deroted a considerable amount of attention to them. I listened with rery great pleasure to Captain FitzGcrald's most interesting paper, and there is only one point $I$ renture to take exception to ; that is, where he expresses diffidence as a naral Oficer in discussing such questions. I think on the contrary that naral Officers should speak out, and loudly, and let their opinions be known, and not allow themselves to be orer-ridden by naral architects. The men who hare to use the tools ought to be the best judges of what tools they want. Although I hare deroted a good deal of time and attention to the endearour to get through the greatest possible thickness of armour, I am the last man in the world to adrocate the abolition of armour. I believe that as the 
locomation of a steam ressel depends on her engines and boilers, and not 0 : sails as in the old days, it is absolutely necessary that those engines and $b$ should be protected. But at the same time one error is made in all these discus and it is this, that attention scems to be concentrated upon the endearour to out the enemy's shot. No doubt that is rery desirable, but there are two $t$ that have to be kept out : the one is the shot; the other is the water. It $\mathbf{I}$ impossible, and I am afraid it is, to keep out shot all round the ship from gu the largest calibre and penetrating power; but it may be possible, at all , partially if not wholly, to keep out the water, and this is how I would sug: might be done. If the armour were brouglit in, say 4 or 5 feet into the and the interrening space tilled with compressed fibre of some bind ren incombustible, that would be more or less self-blocking, it would allow the p: of the shot but tend to close up the channel left by the shot in its passage. last diagrams of the Italian plates, both the Brown, Cammell, and Schneider I at Spezzia, show that the most powerful guns eren if they do not penetrate them up completely; consequently in a rolling sea there would be a great ten for the disintegrated pieces and eren the plates to fall off. But if the armou 4 or 5 feet inside, and the interrening space were filled with compressed the broken armour-plates could not fall off : they would still be there to stc passage of nncther shot. It seems to me that another point has been forgott these discussions, and that is, that if a slot penetrates one side of a ship some about the water-line, it will probably go through the other side very much the water-line, and that would be a rery great danger indeed. The obstr offered by the ordinnry side of an unarmoured ship mould not be sufficient to an armour-piercing shell with no fuze in $\mathrm{jt}$. The passage would be so rery that the resistance offered by 1 or eren 2 inches of iron would be so ins cant that the shell would not burst, and consequently it rould necessarily go th the other side of the ship at a very much lower point. I think if what: renture to term fibrous armour were carried right round underneath the bott the ship that material would hare a tendency to block both holes, and also $t$ protection against torpedoes.

Captain CoLourb, R.N.: Sir Edward Reed rather took me back when I le honour of spenking to his paper the other day, because he thought fror remarks I made deprecatory of going into the armour question on that oce that I did not agree with him; but the fact is $I$ hare not differed from most Officers on that point. I was in agreement with him and with them at the tir $I$ remain so. The lecturer raises debate as to whether this is a naral 0 question or not. Mrr. Barnaby in his recent utterance seems to think it is nc that we rather ought to busy ourselres with those questions of high statesm: which Sir Spencer Robinson referred to so ably in his letter to the "Times." think it is essentially a naral Officer's question. It is as much a naval $O$ question to arrange for his ships with the naral architect, as it is for the in owner of a house to arrange with the architect what sort of a house it is t] wants to lire in. But I think that this all shows a tendency which I am so think is rather on the increase; that is to say, are get to be a good deal mixel what are the boundaries of proper debate for professional men. We Mr. Barnaby and Sir William Armstrong, without a thought of incon; addressing themselres to questions which are really questions of naral tacti nothing else. We had the other day an able and gallant Colonel of the Ingincers speaking of the relatire ralue of the different elements rhich con the power of a ship of war, without apparently thinking there was an incongruous in his taking up that line. The result $I$ am afraid is, so far question before us goes, that it is getting to be supposed that construction gorern tacties rather tban tactics should gorern construction. I hold mysel: firmly and strongly that the naral Officer is to say how he proposes to use th and the ship is to be built for that purpose, and not for any otber purpos. Spencer Robinson has expressed so rery strongly the ricws that I myself hol there is the less for me to say; but I must remark I think the whole question of experiment. When Sir Spencer urges us to press for experiment, he home the chief point of all. We cannot do rrong by experiment. Wo do 
the least mind spending three or four millions on tho biggest experiments going, when we will not spend $50 l$. on finding out whether those experiments are worth trying. I ought to make one remark theugh it trarerses a little what Sir Spencer Robinson has said. I read Mr. Barnaby's manifesto with tle greatest possible pain, and with something approaching to dismay. I will say those words because I lare to adrert to something which he said in his paper. $\bar{I}$ say the words with sorrow, but I think they ouglit to be said. I do not altogether share the alam expressed. Of course when great authorities like Sir Spencer Robinson and Sir Edward Reed express alarm as to these unarmoured ends, I acept it on their authority; but personally I cannot feel the alarm. I think that when we take up the question and use the word "ularm" we are apt to derelop heat, and that the better way is to speak rery calmIs, and reason rery carefully with good experiments, and hare a rery quiet and cool discussion orer the matter; I do not think that Mr. Barnaby fully states the question in his address. He scems to put it as if this belt question was entirely one of destruction, whereas as far as $I$ am able to gather it is more a question of disablement. There is the fear of loss of trim, or a heavy list, throwing jour powers of offence out for a time, eren if you are able to correct it by letting in more water to secure an eren keel. I think there is another danger that we face in leaving the ends nnarmoured, and that is, we accept the unsteady gun platform. Mr. Barnaby puts it that the inertia is sufficient to get orer the diffieulty of the high metacentre, but my experience of two of the most recent ships is that they will be very lirels. I felt in each of these ships in a light swell, as if $I$ were on board a Sfmonite, and coming from the "Thunderer," that steady old rock that nothing disturbs, it occurred to me that the fire from the guns would be rery uncertain. Anyone who recalls the literature of rolling will agree that it is not a question to be left out of sight altogether. I am entirely in aceord with the way the lecturer has dealt with the subject. I think he is right throughout, that the doct rine of chances should govern the armouring of your ship. I do not know that jou can make any armour imperrious; I nerer heard of any except in rery small patches in a ship, and $I$ tuke it a certain number of shot must enter, but my experience of heary gun fire is that it is rery uncertain. It is very much slower, and we know that the number of heary guns carricd is rery much reduced; therefore I think that you will be seldom hit by heavy shot in any rital part of the ship unless you are at very close quarters. In the old wars ships were rery rarely sunk; a sbot between wind and water was quite a rarity, and yet you had then what jou hare not now, ricochet shot. You hare abolished ricochet, and so, I think, you are less likely to be hit about the water-line. I made a calculation taking the best German guns at 2,000 yards, aud I found if you had erersthing absolutely accurate, with a target 3 feet higi abore the water, and fired at the water-line, when tho gun was accurately laid, the target would not bo liable to hare more than 16 per cent. of the slots hit it. The other day in the "Excellent" a target 15 feet high, at 1,400 yards distance, allowed 75 per cent. of the shot to pass citler abore it or below it, though the gun was fired by very careful hands indeed; so that I do not think the danger to the water-line from heary shot is a matter to be rery much feared. It may happen of courso in cases that you will get a heary shot between wind and water, but as the lecturer has said, the shot you must fear are the light shot, becauso of the numbers that will be fired at you. Fou must expect to bo struck a good many times about the water-line by light shot when you need not at all expect to be struck by the heary shot, and the doctrine of chances is that which must gorern your defence. You may carry the thinner belt round the ship with an absolute certainty that you are doing the best for the slip, rather than rery thick plating at one part and none at another. But there is one thing you must do, that is, carry jour deck, armoured if possible, from the top of your armour across your ship fore and aft in order that shot passing abore the belt may not pass out and make a hole below water on the other side.

ddmiral Sir Geonge Elliot : MIy lord, ladies, and gentlemen, I do not intend to detain you beyond the ten minutes which are allowed, and I will endeavour to say what I have got to say in fire minutes. In the first place, I agree with the lecturer in his remarks with regard to the ships with central citadels and unarmoured ends, becausc if side armour is to be used, there is the strongest reason why it 
should be continued as a belt fore and aft, and more especially that it sh cease to exist at the bow. But $I$ cannot agree with the lecturer in this one of his, "No naral Officer, I make bold to say, would hare the slightest obje be sunk by a shot from a 100-ton gun if it hit in the right place." ] should hare the strongest objection, and I reckon that erery naval Officer being blown up, whetler by a 100-ton gun or by a 60-ton, or a 45-ton or a gun. If that gun should penetrate the armour and strike the boilers or ma I say that it is a result greatly to be dreaded, and I do not think any nara would like to be in a ship where he would be subject to such a peril. Th: main point of difference that exists between those who are in farour of side and those who are for deck armour. You hare to look out for the safety magazines and boilers, and the safety of jour buojancy; but I must remarl this lecture the maximum of merit is claimed for side armour, no matter $h$ it mily be. and, on the other side, the minimum of adrantages is allotted other mode of protection. The deck alone is referred to, and all the a which might be applied to that deck are totally disregarded. The decl without the cells and coffer-dams, certainly is an insuficient protection: system of deck protection, if carried ont in its perfection, offers certai adrantages, and I certainly still adhere to the opinion that the ship with th and cellular water-line construction rould be safer going into action thar thin coating of side armour. It is impossible to discuss a question of this so short a time, and therefore I will not attempt to do it. I only wish to my opinion that I still adhere to the adrantages which can be obtained $f$ : system of deck protection if properly carried out, that is to sity, suppleme an claborate cellular construction at the water-line.

Rear-Admiral J.C. WILsox: I will not say much to-night, for in fact all has been said, bejond that I think the paper, whaterer its merits or demerits may commends itself to all naval Officers. It is straiglt forward, eensible, and sear and it points out to the world and those who read our Journal the objection we naval Officers have to the system of shipbuilding at present in rogue. $P$ all been taught that the first principle of war is to attack your enemy at the point, and therefore, supposing we attack ships with these soft ends, I t: would be our duty to concentrate our fire as much as possible on these rul parts of the ship, and hnock a hole in her as quickly as possible, all guns, : large, being equally arailable for the purpose. Then (as Sir Speneer Robinson it) I think 750 tons, or eren 420 tons of water washing about from side to si erery roll or morement of the helm may prove to be a rery disagrecable shipm: Spencer Robinson said, what must recommend itself to all thoughtful naral 1 that it is not our prorince, nor are re capable of discussing intricate ques naral architecture, nor do I think naval Officers often attempt to do so, hare our own particular notions of the machine wo would prefer to fight those ideas I think we are bound to express, and hare a perfect right to do this case we are not arguing upon our own opinions, but from those clea down and forcibly expressed in this theatro by no less an authority $t$ ] Edward Rced, and I think when we heard what he had to say, when we hes distinctly express an opinion that those vessels unarmoured at the water-li: not safe, we hare a perfect right to come formard and state what I beli, bulk of us think - that we concur entirely in his riews, and that we have $r$ fidence in these ships. Now, it may bo said, and I daresay a great num naral architects say it, that we cannot hare a belt of armour all round, heca ships won't carry it. I say where is jour "Dreadnonght," your "Thunderer "Derastation?" They have a belt of armour all round, and if you take tl armour and replace it by composite steel, you can hare a belt of armour same weight which will resist almost any reasonable size gun, or, at any rat as large as any we should send afloat, except possibly in some exceptionally $\mathrm{p}$ resscls. Here also we come to a point in which I agree with Captain Fitz He has not pointedly said "I do not like too big guns," but he has intir preference for small ones, and I entirely agrec with him. I think the sy putting 100-ton guns into Jour ship with a rery fow small ones is a mistake, 1 howerer powerful your guns and jour armour, or howerer strong your sh 
cannot make sted men, and the wholo fighting power of a ship is thus concentrated in onc. or tro men. If these men happen to be a little nerrous, where is your ship? I should like to see the fighting power distributed about the ship ss far as possible. I do not think I shall say more on this subject, but no haro got now some rery good types of ressels, in the Serrice, and it is a great pity if wo do not perpetuate them.

Admiral Bors: My lord, ladies, and gentlemen, I will not occupy my ten minutes, but there are one or tro remarks I should like to make-some in corroboration of what has been said, and in some, perhaps, I may hit on a weal point or two in the lecture. The subject of the paper is "Side Armour versus Armour Decks." MYy impression always has been, and I do not think I am singular in it, that armour decks are simply a substitute for. side armour-that armoured decks were resorted to because side armour could not be carried in ships in which other conditions were considered necessary, therefore it was simply a substitute and not in preference. Whether that substitute is a good one or not is now being discussed. There is one point I should like to touch upon which Captain Colomb referred to, and that is the doctrine of chances in reference to hitting a ship at the water-line. We bare nerer had any definite experiments in that line. Somo years ago, when I was gunnery Officer in the flag-ship on the coast of $\Delta$ frica, I had an opportunity of firing at the water-line of an empty slarer which we had captured and were ordered to sink. She was anchored at 100 yards from the ship. There was a moderate swell on. Our broadside consisted of two 10-inch and two 68-pr. S.B. guns. One whole quarter's allowance of ammunition was fired at her without being able to get a single shot in at the water-line on account of the ricochet. Ono or two entered 2 or 3 feet abore it, through which somo water occasionally lapped in, but tre could not sink her with shot and shell. We had to place a bag of powder at the water-line inside, and ignite it with the "Bickford fuze," which had then been newly introduced into the Nary.

Captain FrrzGencLD: Was it an iron or a rooden ship?

Admiral Bors : It was a rooden ship.

Captain FitzGeraxD : Irad you any machine-guns?

Admiral Bors: We had no machine-guns. That does not bear on the doctrine of chances, but my experiment shows tho difficulty of hitting a ship immediately on the water-line. On the other hand, there is the instance of the "Alabama" and "Kearsage," where the "Kearsage" did place a shell exactly where it was wanted, but if the "Alabama" had been constructed with the arrangements of a modern man-of-war she would probably not have eunk, because her compartments and pumping power would have kept her aflost. Then, the main point in Captain FitzGerald's argument is that large ships with unarmoured ends are to be disabled and probably sunk by the fire of light and machine-guns. I do not agree with him on that point, for I think that although numerous small holes may possibly be made near the water-line of vessels like the "Italia " if fighting the "Hercules," that the slight damage that would be done inside of them would not admit that large quantity of mater which is necessary to affect the stability of the ship, therefore I think his argument there is not quile sound. But, on the other hand, if it were possible to make tremendous holes with large projectiles and blow away tho contrivances inside (which I should), it becomes a question for constructors to say how far the stability of the ship is affected by the introduction of the immense amount of water mentioned by. Sir S. Robinson. There is one other remark I should like to make. Captain FitzGerald says, "I am informed by an experienced gunnery Officcr that the 100-ton gun cannot be expected to fire more than one round in a quarter of an hour or twenty minutes.". I do not think that can be taken for gospel in any way. I maintain that with proper arrengements and drill, and ererything in good order, as it is supposed to and can be, certainly not more than fire minutes should be taken to fire one round. I take this opportunity of expressing my dissent from the plan which $I$ hear is to be adopted of putting two 100 -ton guns in one turret, tying them together as it were, thus tsking probably half the ralue away from both. I would certainly adrocate the necessity of any reasonable amount of money being expended on experiments in order to arrire at something conclusire on the subject of the able paper we hare just heard.

roL. XXIX. 
Lieutenant TUPPER: My loxi, ladieg, and gentlemen, as Captain FitzGe: done me the honour of asking me to give my opinion on his excellent paper: sou will not think it presumptuous, owing to my junior position in the if $\mathbf{I}$ giro it. In the first place, in spito of $\mathbf{M r}$. Barnaby's expressed op the contrary, I hare often discussed with Officers of about my own stand question, and long before the introduction of machine-guns we looked wi distruet upon the modern construction. With the introduction of machi and the quick firing 6-pr. our riews hare been much atrengthened, therefe vers glad to sec that eren Mr. Barnaby soems to bo coming round to our the case in suggesting an armour-belt for tho "Agamemnon." Sir Spencer $B$ in his remarks on the lose of buosancy of shjps did not mention tho " $\mathrm{Con}$ which was mentioned in Mr. Barnaby's tablc. The "Conqueror" is a ne ram. She is armoured all round, excepting just at the stern. She, with una: end perforated, only loses 32 tons of buojaney, and as this puts her dow: stern at any rate, it rould not diminish the stecring power, and might increase it, e.g., tho "Agamemnon." Captain FitzGerald adrocates that $w$ at once alter the cristing type of ships by plncing an armour-belt round the haro now got something like seren of these ships rery nearly ready for the and he says "let us put on tho armour-belts at once at any cost." I hux to differ from him; we hare at least these ships ready now, and rery me more ships. If we put the ships into docksard hands to hare this done, $t$ be laid up there for cighteen months or moro I should Eay, and will therefc use to us if any complications should suddenly arise, whereas if to go ts can at least hope they will gire a good account of themselres before the; they do sink, and if they do not sink all the more honour to those who them. I hare alwasg looked upon the "Drcadnought" as the best ts battle-ship. The "Thunderer," "Derastation," and "Dreadnought" has oecmed to me splendid ships. They are most formidablo ships all round $c$ although they were built so long ago as twelre jears. As regards the mac fircd at close quarters, I think it has tho great adrantage that the man whe it can alter its direction and cleration in a second as he is firing. IIe oui able to see pretty Fell whero his shot are going, and so he can alter the clera at once to make hits. If we put an armour-belt round tho ships, of $c$ must do away with some of the other weights. Captain FitzGerald adroca amay with tho horizontal armoured deck. I agrec entirely with his reI that point, but I think that thicker horizontal armour should bo put ritals, such as the boilers and magazines, than is the practice at present. think, with Colonel Hope, that there is much danger of the shot of macl going through the armoured deck and out through the bottom of the ehip jou hare sereral decks for it to go through at any rate as well as th bottom. I would also say we might get rid of some of the weight by do with fore and aft bulkbeads. Ercepting in the engine and bojler rooms sec much usc in them, because with $a$ foro and aft bulkhead, supposing : two compartments penctrated eas on the starboard side, jou would at o list to starboarl, which in a turret ship would probably put the guns out on that side, and therefore tho Captain rould at once want to admit wat port side diagonally opposite to right her. It is quite possible that the Encw how to admit this nater could not be found, and thercfore wit manocurring power and gun power the ship is at the mercy of the enes The primars object is to keep the ship on an eren beel in order tliat she : well, and longitudinal bulkheads scem to make the cliances of liceling $\mathrm{m}$ mould, therefore, do away with longitudinal bulkbeads except for the en boilers, and if possible put more transrerse bulkheads in so that the ship kept on an eren keel. I will summarizo ms remarks by giring jou a $r$ of mhat I should like to see as a battle-ship. The citadel should liare th armour they could put on it, and this citadel should be a regular sort of taining magazines, engines, boilers, and stecring arrangements, its top bein - with 5 . or 6 -inch horizontal armour. The ends should be armoured w 4 to 6 inches of steel if sou could manage to put it on; all the dec] be of about 1-inch steel, and the clecks should all be fitted with horizon 
tight doors. The guns should be mounted in two turrets in the fore and aft line, perheps only one in each turret, and the bases of the turrets protected by circular towers rising from the citadel, the top of which need only bo about 4 feet abore the water-line. Between the towers you should have your secondary battery of 6-inch guns, as many as possible, which is a rery important thing, and which is to be unprotected by armour, instead of which jou should hare steel shields on jour guns, and have as many transrerse bulkheads as you can in your secondary battery to keep the splinters from flying about the deck as much as possible, and you should hare all the fighting arrangements and telegraphs of the ship in one impregnable position, inside which the Captain stands, haring a good all-round riex, and communications, protected by armour, to all parts of the ship. The ship is to be as small as compatible with these requirements, as I consider two ships, each carrying two of the heaviest guns, vastly superior to one ship carrying four of the heariest guns, and the smaller she is, the less chance she has of being destrojed by gun, ram, or torpedo.

Sir EDWARD REBD : Lord Clanwilliam and gentlemen, I had not any idea, on cntering this room, of speaking to the paper, becsuse I thought it much better tha: naval Officers should express their opinions on this subject, for I regard this meeting as one of the most important I hare erer attended, because it has been opened by a very thoughtful and carefully written paper by a naral Oficer, on questions on which it is of immense importance for the naral architect to know the naral Officer's riers. I am bound to say I beliere the naral constructor is made a great deal too much of in these debates. I agree with Captain Colomb when he says that it is the duty of the naral constructor to design the ship which the naral Officer requircs. Now there is not the shadow of a doubt in anybody's mind that the Admiralty staff as it has been constituted for many jears past is perfectly capable of designing any ship whaterer which the naral officer wants, and therefore if wrong ships get introduced into the Nary it can only be because the naral Officers, of whom there are many within the Admiralty, scem to fall short of their duty, and gire too much scope to the naral constructor in turning his office into a place for inrenting ships of his own, instead of for building the ships the Navy requires. Lieutenant Tupper in the interesting remarks which he has just made, in selting forth to design his own ressel started with what, if I may be allowed to say so, I regard as the fundamental error which all persons fall into when they start to design a ship-of-rar. He said he rould make the ship as small as possible; but what you want in Jour ship is what should determine the size of the ship. You cannot start by saying you will have the smallest ship you can get, and then go to work and put the utmost protection possible upon it. What sort of system is thatto start with a rery small ship, and try to put into that all you require? I lay down the rery contrary proposition, and regard as lying at the rery basis of this whole question the fact that the country has not been under the necessity of defining the size of any ship by any other consideration than the qualities which it is necessary to gire to it. I think I shall be borne out by many naral Officers in saying that putting pounds, shillings, and pence aside, there is no particular adrantage in small ships. Some of the largest ships we hare are some of the handiest, and in erery way fit to fight the country's battles. But the real fact is that jou start with the iden of spending as little as possible on the ship, and then you get into some miserable altereations into which Captain FitzGerald has been driven, namely, how are we to get the weight we want to put on the first. class battle-ships, - how are we to get enough armour eren to keep out the shot of machine-guns? The whole state of things is preposterous. Nobody erer need hare first defined the size of the "Ajax" or "Agamemnon" and then hare said, "Eren if we cannot protect the ship against machine-guns without making her a bit larger, we will not do it, but will rather expose her to destruction by these machine-guns." The next thing $I$ want to say is this : that in so far as any danger to these ships is concerned, the introduction of machine-guns has nothing whaterer to do with the question, because erergone must hare known what I often pointed out, riz., that when the designer produced a first class ship for the British Navy which a small gun fired quickly could destroy, he rould assuredly have that ship destroyed by small guns fired quickly. The inrention of the gun is the result of the inritation which has 
been held out to our enemies. Allow me to explain in a mord or tro how this whole matter has arisen, and where we really stand. I do this the more readily because I shall bring into riew in a word or two the differences of opinion which prevail between some distinguished naval Officers and myself. There is at the present moment a correspondence going on in the "Times" on the question. Supposing we take Fig. I to bo the water plane of a ship; supposing she is a fine-lined ressel

FIG. 1.

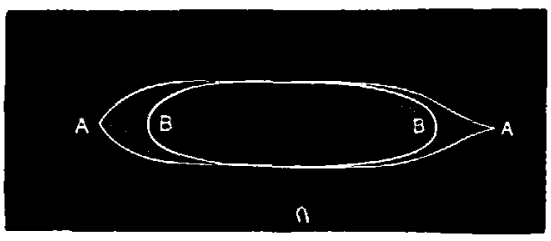

intended for great speed. I am rery strongly of opinion that there is no necessity to carry the armour out to the ends at $A$ and you might well form your armour in the way shown at $B$ and leave the ends without armour to something like that extent. Captain Colomb has rery properly pointed out that there aro two things inrolred in this question, first, the element of danger, and secondly, the element of disablement. Now as regards the clement of disablement, it is clearly a question which the naral architect has nothing to do with, and about which ho cannot know rery much, unless he consults with naral Officers and finds out, he cannot be a good judge of how far it is safo to bring thisarmour away from the bow of the ressel. A naral architect will tell you perfectly well how much water you will let in when the ends are injured, but only the naral Officer can tell how the ship will behare under the conditions of leting different quantities of water into her. Up to this time, although I hare becn so much concerned in this controversy, I hare never anywhere expressed an opinion as to how far jou could bring that armour away from the bow, and still arert ererything like speedy disablement. What the Admiralty did was to go to a most extraordinary extent of contraction all at once. That is the question which has been before the country for years, and has caused me the greatest pain and anxiety of my life. I initiated the question at the Admiralty as to how far it was possible to contract the armoured part of the ship and still leare its citadel big enough to possess sufficient stability to keep the rhole ship upright. While I was discussing that question and making preliminary investigations about it, I left the Admiralty; but when I had clearly made up my mind that there was a limit bejond which it was not possible for anj one not absolutely out of his mind to think of going, on the other hand the question remained to be determined by careful inrestigation and consideration, how far can you go between that jimit and the other limit of a complete belt, still relaining not only safety but reasonable precautions against disablement? That is the course which I should mygelf hare taken bad I carried the ssstem out. But what did the Admiralty do? Instead of dealing guardedly with that problem, beginning by shortening and gradually approaching to what I regard as the clement of danger only almays taking care to keep a long way from it, they made a clear sweep of the bow and stern armour, and armour-plated one-third only of the ship, as shown in Fig. 2; and flled up the rest partly with cells, and coffer-dams, stores, coal, and other things. With all deference to Lieutenant Tupper, Coloncl Hopo wa: perfectly correct in saying that in theso ships, whero so many guns are capable of penetrating the unarmoured ends of the ship, they will be attacked by depressed fre, and the shots will go out of the ship on the opposite side of her and below the water. Then this question arose-and this was the whole of the "Inflexible" controrersy so far as I was concerned : I Eaid "There is not eren enough of that slip armoured to keep her upright as regards stability when theso ends are riddled." Then the answer was, "Oh, but there are coffer-dams, and cells." But ] 
Fro. 2.

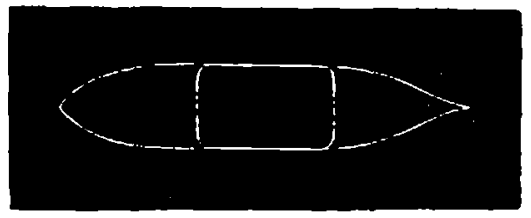

say that any shcll from the smallest gun that then existcd, as also from the smallest gun that now exists, will penetrate the cells and coffer-dsms; and I ask Officers to remember that there is no porrer in any cell or coffer-dam made of thin stecl to keep out any shell whatercr. They nre capablo of being perfectly riddled, and when Adniral Bors spenks about water not readily lowing in, upon my honour I am at a loss to understand why a number of small holes will not let in as much 88 a single larger one, and how any hole will not let water in until it is stopped. It is absolutsiy absurd to suppose that under the conditions of closely contested naral actions you will be able to eend men out of tho armoured citadel into the unprotected parts, to stop all these little holes. It is entirely preposterous. Thence aroso the controversy. Fow what I say is, it was nerer right-no ressoning, no arguments, can erer hare made it right for one single moment-to build firstclass ships with citadels which rere in themselres insufficient to beep the ship upright, and afloat. That proposition I lay down with confidence. But if built, it was ccrtainls not right to call then first class British ironclads, and ocnd Britiels Officers and men into the line of battle to fight in them. That is the only thing I here crer contended for in public-that the British Narg elould not bo condemned to go to ses and into battle in ships with so much armour denied them as to leare tho citadels too small to kecp them upright. I think there is a great deal of truth in Captain FitzGcruld's paper, all through it, but I do think that eren now the danger of capsizing is not understood. I beliere it is not understood in the Italian Marine. I beliero that no man in bis senses would erer hare designed such a ship as the "Italiz" if bo had fully realized tho danger of the ship capsizing when but little injured. Now Admiral Sir George Elliot said just now that he stood by his riew about the armoured deck. I want to make a remark about eren such a deck as Captain FitzGerald sketched on the board; because an element of danger crecps in there which naral Officers would not recognize so readily as a naral architect. Captain FitzGerald drew a ressel of the hind shom in Fig. 3 mith an armoured

Fro. 3.

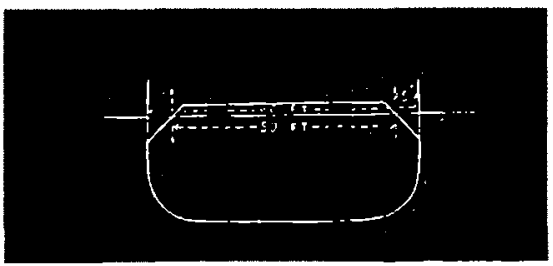

deck of the sort shown, and I belicre it is that kind of deck that Sir George Filio intended to farour. Roughly speaking, as is well knorn to many here, we may oay the stability of the ship raries with the cube of the half breadth of the ship. Now supposing the ship is 60 fect brond, and only 50 feet broad where the water plane cuts the sloping deck; that is a difference in breadth of 5 feet on cach side. Now what is the half of 60 ? 25 , and tho cube of 25 is 15,625 . What is the half of 60 ? 30 , and the cube of 30 is 27,000 . Now obscrre what has happened. By letting the sea in, and thus reducing the rirtual brcadth from 60 feet to 50 fect, 
sou bare reduced the stability from 27,000 to 15,625 ; that is, 5ou hare only Iralf the original stability left. I beliere persons who adrocate the letting $t$ into the ship abore these armoured decks do not realize the effect upon tho sta of the ship. Now I am weak-minded cnough to care a great deal about stal I agree with Captain Colomb about disablement, but I do' think the proposterous thing in the world is to build ships with a great deal of ar deroted to the protection of their boilers and their guns, and then to leare the themselres at the mercy of any gun whatever to turn them bottom upx Can madness go further than that? Sir Spencer Robinson referred to extensions of the citadel which haro been mado in more recent ships of Admiral clsss, and I wish to call attention to a matter connected with that. quite true that in recent ships the citadel las been somewhat extended in le but it has been lowered a great deal in height, and the fact is, if you take one c Admiral ships and put her alloat in front of jou, and gire her a list (and at a loss to know how you are by any contrirances to prevent her listing injured) of 5 or 6 degrees towards sou, all the armour will disappear from viow; so little armour is allowed. I do not at this moment complain of th: am only cndearouring bere to state the issues that hare been and are at sta. this question. Now in answer to that it may be said that just as it is true th the ends .9 great many derices hare been resorted to for the purpose of ket water out, so a great many derices haro been resorted to abore the armoured of the $\Lambda$ dmiral class for the same purpose; but there re come to an question which naral Offeers only can answer. Will the naral Ofiticers here it quite clear in the course of this debate whether they think that mere subdir that is, the dividing of the unarmoured part exposed abore the armour prote into thin armoured cells, is sufficient to keep the water out, or whether shot shell will not riddle them and render them useless? Of course I know ratertight chambers and cells-are excellent derices to apply to a sinip belor armour, and also when jou hare imposed upon you the sad necessity of kec dom the armour to the lowest possible point. But what is the object of $t$ How is it that we cannot gire our ships more armour when they requir No other circumstances than naral weakness, want of courage, want of $d$ mination to keep this country in its proper position hare driren us to this nece: Nothing has happened to us jet-Flearen knows what may happen-to ma. incapable of building the ship we want, and if 10 feet deep of armour will mak. ship safe wo must hare 10 feet and not 5 feet only. I am not speaking of secor third class ships, but of the armoured line-of-battle-ships of England, which to seek out and not to run away from the enemy. It is against the $p$ genius of the country and of the naral profession that they should run araj. must seek the enem5, and close with him; and I say it is a wrong, I would ere in my opinion it is a shameful thing, to withhold from such ships the nece: amount of armour. If we correct any error on this point, for Heaven's sake I make it on the right side, and put a little too much rather than too little arr upon our first class ships.

Lieutenant TUPPER : I only meant by a small ship that it is better to havo shipa carrying two guns each than one with four guns. That is the principle, in my remarks about the penetration through the deck $I$ was alluding to plunging fire of machine-guns.

Admiral SELWYN : My lond and gentlemen, I wiah to attack the subject of paper directly in this matter. Captain FitzGerald has giren us apparently a ch between two things, to both of which he aseigns a certain ralue, side armour under-water deck armour. I do not think there is anj Officer in the Nary would not be delighted to hare both, and I only rise to saj there is no other re: whaterer except prejudice why both should not be employed. The only obstac: be orereome is the addition to the weights, for we cannot consider the question the expense when talking of the safety of ressels that hare cost millions of mo The question of the reight is the whole question. Is it possible or is it not to 1 cngines which weigh 112 lbs. per indicated H.P., instead of engines which wi $308 \mathrm{lbs}$. per indicated H.P. I say that has been prored to my own knowle during the last 10 or 12 jears. We can hare ongines weighing per H.P. al 
one-third what they actually weigh in the best compound engines. Again, ve can hare armour properly made of which 9 inches will suffice to keep out any shot that will erer be used on board ship; but we hare not suffeiently deroted our time to making experiments on these subjects, therefore we are still arguing orer the disposition of a few tons of armour that we think ourselres able to carry. What we ought to do so is to push forward with great attention all these economies which hare reference to weights. If a compound engine has giren us moro power and less weight than wo had formerly, a still further adrance in the same direction has been prored possible under our own ejes, which will gire us what I speak of. If jou calculate 5,000 indicated H.P. at $308 \mathrm{lbs}$. per HI.P. and reduce it $200 \mathrm{lbs}$. on each H.P. you will see what a considerable weight you hare sared. If you go a little further and calculate the economy of fuel which may be made in these engines, if you sce that these new engines can do and hare done for years with $1 \mathrm{lb}$. of fuel per II.P. instead of two, then you have another economy of weight which you may dispose of as you please. These things should be made the subject of steady experiments, not on the scale of 12 inches to the foot, for that is a sort of experiment which I totally despisc, and not experiments which are going to cost a great deal of money, although I consider any such money so spent would be wisely spent. At the root of all this difficulty is to be found a false marim of political economy, which tells us that the expenditure of money within the country is to be aroided by all means, and to bo talen credit for if economized by either party in power. This is the root of the whole question. Once persuade the Cabinet that no expenditure within the country is unwise which produces good effect in supplying accurate knowledge, and then jou will tind cach party taking credit for having epent more in this way than their predecessors. When that is done we shall get reaults which until then we cannot hope for. Then we can have under-water deck and increased armour in erery direction, and there is no earthly reason why we should not, except what I hare pointed out.

Mr. W. H. White (late Chief Constructor R.N.) : $\mathbf{M F}_{\mathbf{y}}$ lord, ladics, and gentlemen, I stand here as the professed friend of the Admiral class as they arc being built. I say that at the outset, and I do not pretend to be able, in the time at my disposal, to justify the opinions I shall express; but $I$ repeat what I said here in the debate on Sir Edward Reed's paper the other day, namely, that it would be diflicult if the ships had to be designed over again, within the same limits of cost, to produce a better combination of speed, armament, and defence than is to be found in those ressels. I would like to add that I do not now challenge Sir Edward Reed's main position, that for this country it may bo desirable to put aside questions of cost. I only say that the naral architects at the Admiralty inrariably hare that condition of limited outlay put in the forefront in carrying on their work. As one who until recently was at tho Admiralty, who has undoubtedly to bear a considerablo share of responsibility for the designing of the Admiral class, I would liko to say, on bchalf of $\mathrm{my}$ former collengues, that $I$ am sure nono of them shrink in the least from criticiem of those designs, they believe them to be honestly good ships. within the limits in which they were compelled to work. Then it must be remembered that the naral archi. tects in the Admiralty are not such despotic people as seems to be supposed from some of the remarks made here to-dsy. . Of courso that has been put right by other speeches. The facts are that the constructire staff in the Admiralty are always working under tho direction of the Board of Admiralty, a majority of which Bosrd consiets of naral Officers. At the time of the designing of the Admiral class a number of alternatire propositions were considered and put before the Board, of rhich Lord Clanwilliam was then a distinguished member, and the Board haring before them a full statement of what could be done within the limits of cost, eclected this design for a barbetto ship as the best which could then be had. It may be true to some extent that the conditions are varied by the subsequent introduction of machine-guns and rapid firing guns. My own opinion is entirely in accord with that of Sir Edward Reed, that the derelopment of such guns has gronn.largely out of the shrinkage of the armour. But that has gone on ererywhero; it is not confined to our ships. It is perfectly truo that in our shipe the enda hare been left unarmoured for a certain shallow depth below. water. 
It is true that in the French ships the belts are carried from end to end; but what seems to be cometimes forgotten, and what, so far as I am able to judge, is almost entircly omitted in the paper, is that armour has been shrinking in its rertical extension as well as in its longitudinal. In some of the French ships the armour is only 2 feet abore the normal draught. What about teeping the small shot or shell out of the parts of the ships immediately abore the belt? Do not let us, while paying such special attention to tho longitudinal extension of the armour, forget to admit that there has been a rertical shrinkage. ' If jou admit the principle that armour should be used to protect stability, which is the principlo Sir ldward Reed maintains, and which he has a perfect right to maintain, but which $I$ do not accept, and which is not unirersally admitted, then I say this rertical slurinkage of the armour is a much more serious matter than the longitudinal diminution of its extent. I have no time to argue that matter out now. I let the statement stand, and at a proper time and place I shall be quite prepared to justif $y$ it. But take the facts as they are. Ifere is the water-line [draming]; here the protectire deck; here is the armour; here is the upper deck; and here ordinarily in a detached battery stand the guns, whether in turrets or barbettes. Whether the belt goes to the end or not you hare all the rolume of the ship situated aborc the belt and bfiow the uppermost deck, into which shells from the lightest guns can pass. I think that is a rery important fact, and I say as regards the "range" of stability, the French ships are practically no better off than ours, notwithstanding their longer belts of armour. I myself made the calculations for the $\Delta$ dmiral cluss, and should be prepared at any time to produce them, and I should hopo that after the discussion that has taken place to-day, there will be some proper inrestigation, and an authoritative statement, which shall show that theso ships are not such cripples as we are asked to beliere they are. These ships of the Admiral class haro "initial stability," supposing the whole of their ends to bo thrown open to the sea and waterlogged. As regards the use of armour to protect the ship against upsetting, which is the great point Sir Edward Reed laid stress upon, I say the belt from end to end is not an imporiant factor in the problem. As regards the stiffness of ships of the Admiral class, I say the armoured citadel has in itself sufficient exclusion of water to gire them that stiffness. In reply to Sir Spencer Robinson's remarks about a gradual improvement in grace on the part of the constructors, I may say that the lengths of the belts in the rarious ships were determined by the lengths requisite to protect the machinery, boilers, and communications from the magazine to the guns, the growth in length arose from changes in theso conditions, and not from a desire to protect a rreater percentage of the water-line area.

- Sir Spexcer Ronissoy: You do not object to the growth?

Mr. Wrire: I only say it mas not a question of stability or sinkage, but of length required to protect communications. There are so many points to refer to, and it is getting late, but wlat I want us to be clear about is, I vould not for the world have it thought that an expenditure of something like four or fire millions has becn incurred with our ejes shut to the dangers and possible risks which ships of this class may run. No ships can fight without running risks, and I say the balance of risk in the Admiral class is a good one. That is my opinion, and it was the opinion of the Boards of Admiralty which ordered these slips, and the ships were accepted after one of the most eareful and extended discussions by the full Board I have erer known. With all respect for the great body of naral Ofiecrs, $I$ think it may well be donbted if with equal numbers you could at any giren timo obtain any Committee better fitted to discuss questions of this kind than is to be found in a Board of Admiralty. The question of the use of armour seems to me to be at the root of the whole matter, and the sooner we get this question investigated by a competent body, naral architects will be able to proceed with more certainty. Is armour to be used to protect buogancy, stability, and trim, or to protect the ritals from shell fire? The sooner theso questions are answered the sooner will it be an easier task for the naral architect to proceed with his work than he has had for many years.

The Crrarryax : I only want to say a rery few words. Mr. White has just remarked that these ressels were built by tho Board of Admiralty. Of course there were no machine-guns in those days, and I rery much doubt if the Board of 
Admiralty would hare passed such a reseel if they had known it could be turned into a pepper castor in a rery short time. Supposing we are on the enemy's coast blockading a port, and are attacked by gunboats. The fore end of the ship is riddled by the gunboats; it is filled with water; it is that part of the ship in which the crew lire; then the other end of the ship has to be filled with rater to keep her on an eren keel. Then she draws very much more water, becomes rery unhandy, very diflicult to manceurre, and totally unfit to keep the sea as a British man-of-war.

Captain C. C. FitzGeraid, R.N., in reply, said : I will begin at the end if I mas. Mr. White, the great champion of the citadel ships, has given us his opinion, and I must say I am a little disappointed that something more has not been said in farour of them than Mr. White has been able to say. I do not profess to be a naral architect, but I rill point out one or tro things in $\mathrm{Mr}_{\mathrm{r}}$. White's statement. He gays it is a question of money. No doubt of it. That is entirely correct. The says that a fair proportion of risks hare been orercome, that he has struck a good balance between the different requirements, and that if lo had to design the ships over again he could not do better.

Mr. WHITE: Under the same giren conditions and cost.

Captain FitzGersid : Then hy points to the shrinkage of armour on all ships. The point I take particular exception to is his comparison with the French ships. He has drawn only a section of the ship here. A French ship has a complete belt of armour. I am not entering into the question of the thickness, though I beliere they hare armour almost as thick as we hare. He says it has shrunk rertically in the French ships, and that it is no higher in the French ships than in ours.

-Mr. WHITE : Lower in some cases.

Captain FrtzGeraLD : There appears to be just this difference. If I stick to my citadel, and then make the other part armoured deck only [draxing on black board]. But in the French ship, completely belted, the top of the armour is corered by an armour-plated deck, so that the space below the deck is as safe as in the other ship. And although she may be kanting in stability under sail, the buoyancy represented by what is corered by armour and armoured deck is greater than is neceseary to float the ship. There is a reserre of 2 feet, which represents about 1,000 tons. In the English ship, howerer, jou take aray that and let in some 600 tons of water. That is in her best state, with her coals and stores in; and I maintain that that is a misleading statement, as ber condition will be worse under some other circumstances.

Mr. Wnite : May I at once explain, because I am sure Captain FitzGerald would like to be put right: I beliere Mr. Barnaby's figures represent the ship as she would be if starting from her loaded draught and rater were admitted. If the coals and stores were out, of course the ship would start with a lighter draught before the water was admitted, and therefore tho water which can bo admitted from the water-line domn to the deck will be much emaller than in the other case. I think Sir Edmard Reed will admit that tho rorse condition is water falling in."

Captain FitzGeraId : It is not really tho point. 500 tons of loose water would be admitted into the "Collingsood". with her ends riddled. Mr. White then led us to suppose she would be in an equally good condition with the French ship. 500 tons of loose rater! Does any one suppose the ship is going to remain upright rith it? Snrely that water alone will double or quadruple any list she may acquire eren in turning. She cannot be compared to the French ship for anfety. The French ship has got flosting power enough to keep her upright and intact as she is, while the English ship has 500 tons of water in her. Why a little list must be enormouely increased, and the smallest shot hitting her unarmoured ends can put her in this condition. I do not know whether there can be any answer giren to that. Mr. White has made a rery able defence of the citadel ships, and there can be no doubt the whole gist of my lecture was an attack upon them. I want to put

1 Pressure of time prerented me from stating that instead of twenty minutes being the interral required for loading and fring a 100-ton gun as supposed by Captain FitzGerald, about four to fire minutes are sufficient. 
together a few points which I think may hare some weight in the matter as sh that not only naral Officers, but architects themselres, do not appear to be per eatisfied with these citadel ships. I hare here the Report of the "Infler Committec. I nced not recapitulate what Sir Edward Reed says here. It i clear, and he points out that he has tho grarest doubts about these ships. is a large mass of eridence, but after they hare summed up and said that ships under all probable circumstances of battle will be safe, they point out $t$ thrce things which throw a grare doubt on their conclusion; and I suppose if ] a lawjer I should apply for a writ of error on the ground that the rerdic contrary to the eridence. It really is as plain as that. You are told that you not rum your gums out on the came side, and you muet be rery careful how yo Jour helin orer for fear of upsetting the ship!

Mr. Wirte: The Admiral class wero not designed at that date.

Captain FitzGerald : It is only a modification of the other, and the Ai class are almost as bad as the "Inflexible" class, because if the ship abo" arnoured deck is full of water, the list will be sufficient to bring the armour 0 : citadel under water. I do not question but that they are an improrement. ought to be, of course. There is another question which has not been broug now, but it is a rery zarious one, that is, the longitudinal stability of these What I mean by longitudinal stability is that they tip under these condition the "Inflexible" receired in her unarmoured bow near the water-line half-o. shot-holes of the shape of a scoop-the shape that might reasonably bo suf to be caused by ordinary gun-fire-she would go down by the head entiri hare to stop her engine. She absolutels tips to that extent that at a speed of knots, if she has one or two holes in her, she must stop or sink. That scems a point somerhat lost sight of. Very exhaustire experiments kere carried c Mr. Froude at Torquay, and I cannot imagine that the ship itself could s worse condition than was shown in the model, so that they aro rery dist ranting in lateral stability and longitudinal stability. Another point about ships is this. We are told that one element of eafety in them is that loose on deck checks rolling and extinguishes it, and the Chief Constructor did $r$ honour to describe to me an experiment made in the "Inflexible." He ment. Gibraltar in the "Inflerible," and let in 70 tons of water, and he says you: not hare known it was there if you had not been told. But it has the rema: effect of extinguishing the rolling, and they say she will keep upright becau rill not roll. That seems to be based on a rery minor experiment. I cannot, see what 70 tons of water has to do with 500 or 600 . It seems to have no re or connection. It is just the same as if a doctor ordered a paticnt to take a of strjchnine or arsenic ; it might hare a rery good effect, but that is no 1 why ten times that amount would not kill the man.

Mr. Wurte: If Captain FitzGerald will read through the "Inflesible" $R$ he will find appended there the details of an experiment where the full quan water that could come in in the model did come in.

Captain FitzGerald : I have seen the model, and it conreys nothing mind. In the first place, it is not a correct model. I do not disputs th centre of grarity is in the place where it ought to be, but they hare lower top reights and brought up the bottom ones to get it there, and the mode not represent dynamical stability, only statical.

Mr. WHIte : I am not speaking of the Admiralty model, but of the mc the Committec.

Captain FitzGerard: It has nothing to do. with the behaviour of the 8 sea with 700 tons of loose water on the deck, and naral Officers will ne satisfied until it has been prored. I cannot read private letters or mention ? but I hare a letter from a Chief Constructor in one of our priccipal dockra which he sajs, "I wish I could aseure jou that this ship (naming one. Admiral class) was perfectly safe under all circumstances when the bottom n pierced, but I cannot go quite so far as that; in certain remote continge should quale for her; but $I$ do say that there must be a combination of unt events, which are rery improbable, before the ship would bo dangeronsly ur Now, that combination of untoward erents is just what noral Oflicers thin 
occur, and that naral architects hare made up their minds will not occur. Anotber point is the fact that the Chief Constructor in his manifesto absolutely proposes to put 2-inch armour on to the unarmoured ends of our battle-ships by lesring out one-third of the ammunition. To me that was a startling concession. Either those ships do not require that armour or else they do. If they are safe without it, why is tho proposal made? May not we assume that the rery man who designed them has doubts about them? I cannot help thinking that that is one of the strongest points against them erer put before the public. Supposing the naral architects could prove to us by most elaborate figures that these ships were perfectly safe, I etill think naval Officers would have something to say upon their merits. They would say, "It is an untried machine; you put this invention before us, Jou tell us to take the ship to sea and into action, and here is a printed paper of what we are to do when our ends are riddled." "Fill all compartments of after deck aft ercept coal space." This is an official memorandum of the "Agamemnon" and "Ajax." "Fill all compartments," \&c.

[Captain FitzGernld here read the printed instructions as to the amount of water which was to be roluntarily admitted into the "Agamemnon" and "Ajax," in order to restore their trim in case one end was riddled by shot, and not the other.]

To tell a Captain with his ship half sunk to let in inore water! I really thought it was the duty of the enemy to sink our ships. It seems to me jou are going to help him. Mr. White laughs, but it is no laughing matter. I do not think any Captain would let in more water when he thought his ship was sinking, but he would do his best to keep it out. It really seems to mo that these devices are not practicable; they are certainly unprored. It presents itself to my mind somewhat as if somebody told mo be had inrented a brand-new flying machine by which I could fly to Cherbourg and come back in time for dinner. IIte might prote it was strong enough. He might say, "This ming is made of Besscmer steel, and this ono of whalebone, and so on," and tell mo that all I had to do was to turn a tap and cock my tail when I wanted to come down, but my remark would be, "Go and try it yourself." There is only one other point. One thing they claim for these ships is that they hare concentrated the armour; because they cannot keep the shot out altogether from the wholo part of the ship they make this certain part impreg. nable, but really their argument is cut from under them; becauss the 16-inch armour is not impregnablo-it can be piereed, as Mr. Barnaby himself tells ns, the Spezzia target orer 2 feet thick by the heary guns of our enemies, so that they hare not mado any part impregnable. So far from having struck the best conditions, I renture to think, with all respect to them, that they are quite at fault. They hare not done what they intended to do in keeping one part impregnable, and they have left the ends, os Sir Edward Reed said, so little protected as to endanger the safety of the whole ship.

The Crrsmusx : I think you will all join me in thanking Captain FitzGerald for this opportunity we hare had of discussing the subject. I am only sorry it has been so short. 